\title{
TARRAGÓ, Griselda, De la orilla del mar a la vera del río: navegantes genoveses y comerciantes en el Plata y el Paraná (1820-1860), Ediciones Prohistoria, Rosario, 2011, 237 páginas
}

La migración es un fenómeno complejo y heterogéneo objeto de investigación de diferentes campos de estudio tanto de las ciencias sociales como de la filosofía. Los cuantiosos escritos y los debates intelectuales que se han generado a partir de las diversas líneas investigativas reflejan en gran medida las perspectivas ideológicas y políticas vigentes en el contexto de producción. Sin embargo, aquellos planteamientos teóricos que han simplificado el marco analítico y generalizado las respuestas a las múltiples preguntas que emergen del examen de los flujos migratorios, han resultado insuficientes dado que presuponen una objetivación de un proceso cuyo examen no solo requiere un enfoque multidisciplinar sino además una revisión y conceptualización permanente.

De la orilla del mar a la vera del río: navegantes genoveses y comerciantes en el Plata y el Paraná (1820-1860) es una de las cuatro obras recientemente publicada, que integra la colección Las Ramas del Sauce dirigida por Darío Barriera y auspiciada por la Secretaría de Industrias Culturales del Ministerio de Innovación y Cultura de la Provincia de Santa $\mathrm{Fe}$, en el marco de la convocatoria "Espacio Santafesino 2010."

Esta obra, originada en la tesis doctoral en Historia que Griselda Tarragó realizó en la Universidad de Milán, cobra especial importancia en la medida que pone entre paréntesis la abundante literatura que con algunos matices enfatiza el proceso lineal de los movimientos migratorios y las concepciones asimilacionistas de las sociedades receptoras, así como los estudios de enfoque cuantitativo y aquellos que acentúan las variables expulsión-recepción de los inmigrantes. En la delimitación del fenómeno migratorio que trata aquí, la autora considera la importancia de los avances en las investigaciones que incorporan a los sujetos como principales protagonistas que ponen en relieve ciertos aspectos del comportamiento social ausentes en los enfoques tradicionales y examina la dinámica migratoria como práctica global en la transición de una economía antigua a una moderna.

Cada uno de los cuatro capítulos que integran esta sólida investigación se sustenta en un valiosísimo y variado corpus documental integrado por fuentes de carácter nominativo, como son los registros de embarcaciones y pasajeros y los censos de personas; fondos consulares; cartas oficiales; actas capitulares; escrituras públicas; expedientes civiles; estadísticas y otro tipo de documentación oficial que se encuentra en los archivos que corresponden a las regiones que la autora analiza. Así también se destaca la amplia bibliografía que cita a pie de página.

El primer apartado refiere a la situación en el norte de la península itálica: el reino de Cerdeña y Piamonte estrechamente relacionado con la dinastía de Saboya cuyos orígenes se remonta a tiempos medievales y de suma importancia en el equilibrio de las tensiones europeas durante los siglos XVIII y XIX. Por otro lado, el repaso histórico por los inten- 
sos debates políticos, económicos, religiosos en la Liguria, región marítima, mercantil y financiera, le permite a la autora sintetizar el período que se extiende desde el dominio francés, el reinado de los Saboya y las tensiones y enfrentamiento de dos regiones que se estructuran con diferentes perfiles, las ondas revolucionarias, la transformación política y social bajo il Risorgimento y el posterior proceso de unificación italiana entre 1860 y 1870. Luego Tarragó gira su mirada hacia el continente hispanoamericano, particularmente hacia el Río de la Plata y los sucesos a partir de 1808. Concentra su atención en los conflictos políticos y económicos, la propensión hegemónica porteña en tensión con las pretensiones autonomistas de las provincias, la experiencia rosista, la confederación urquicista y la construcción de un orden estable.

En el segundo capítulo, sin dejar de mencionar la experiencia de migrantes aislados, intelectuales y profesionales provenientes de la península itálica en tiempos de la colonia, la autora disminuye la graduación óptica e indaga la presencia temprana de sardos que con un flujo constante desde 1820 se afianzan en las orillas del Plata y del Paraná y en Montevideo. La referencia previa a los procesos políticos, sociales y económicos decimonónicos correspondientes al Reino de Cerdeña y Piamonte, y al Río de la Plata contextualizan el punto de partida y de arribo de los migrantes objeto de estudio. Ambos espacios comparten la experiencia política en cuanto transitan la fase previa a la conformación del Estado moderno y experimentan la ausencia de dispositivos institucionales y jurídicos legales que pretenden controlar y ordenar la movilidad de los inmigrantes. El capítulo remite al desarrollo de las actividades navieras de sardos y genoveses, que a pesar de sus permanentes tensiones, supieron desplegar estrategias económico sociales para sortear el clima complejo imperante durante la conflictiva coyuntura rosista desarrollando actividades navieras tanto aquellas relativas a la construcción naval, al comercio de cabotaje, al tráfico ultramarino u otro tipo de trabajos calificados. Destaca en este punto figuras tales como Giovanni Batista Cúneo y Giusseppe Garibaldi que se vinculan a los avatares políticos del momento; así también resulta particularmente interesante la referencia a la no menos conflictiva instalación del Consulado del Rey de Cerdeña en Montevideo y el juego diplomático durante el bloqueo anglo francés.

En un tercer momento Tarragó focaliza su estudio en el "Litoral de los Ríos" y la dinámica de los circuitos mercantiles entre 1810 y 1840, así como en la emergencia de la ciudad-provincia de Santa Fe considerando la reconfiguración del espacio y los vínculos comerciales desde tiempos coloniales y el incipiente surgimiento de la Villa del Rosario en el siglo XVIII. A través de una clara síntesis de las primeras convulsionadas décadas decimonónicas, da cuenta de la adaptabilidad no siempre satisfactoria de los comerciantes rioplatenses frente al impacto y los efectos del predominio mercantil inglés que transita desde experiencias operativas aventureras a relaciones con el poder político y acuerdos diplomáticos. Luego la autora refiere a la inserción estratégica de migrantes ligures, dando a conocer el registro de las naves y de algunos pasajeros que arriban a Montevideo y Bue- 
nos Aires entre 1823 y 1845 , de este modo introduce al lector en las huellas de los nombres propios de familias y grupos que se radican en enclaves litoraleños.

En una escala de observación más reducida, en el último capítulo Tarragó se detiene en la historia de Rosario y en la migración ligur entre 1840 y 1860. Expone las intensas transformaciones económicas y políticas del período y mediante un trabajo exhaustivo de fuentes, explora las trayectorias de los agentes y sus acciones considerando los recursos tanto materiales, relacionales y simbólicos que los genoveses supieron desarrollar al momento de su llegada e inserción. El detalle nominativo de los inmigrantes y cadenas migratorias así como la de sus actividades, brinda tanto al lector en general así como al especialista la posibilidad de ahondar y comprender el comportamiento y la experiencia de una migración temprana y su incidencia en la configuración urbana y rural.

Desde sus primeras páginas el texto invita a su lectura y ofrece una relación dialéctica de los complejos procesos históricos en dos espacialidades distantes. Sin una delimitación territorial previa, la autora avanza con fundamentos teóricos y análisis de fuentes hacia niveles explicativos que construyen el espacio a partir de un ida y vuelta entre un enfoque micro y macroanalítico. Tarragó, que pone en suspenso las explicaciones generales, logra la inteligibilidad de los procesos migratorios en la historia local y regional recuperando la dinámica hombre-espacio en una realidad discontinua y heterogénea en vinculación al sistema capitalista en expansión que la contiene.

Liliana Díaz CEDCU- UNR 